\title{
Using Online Banking Among Covid-19 Pandemic: A Systematic Literature Review
}

\author{
Manal Al-Zatari* $\quad$ Saeed Abu Reehan \\ Palestine Technical University-Kadoorie, Tulkarm, Palestine \\ * E-mail of the corresponding author: manal.alzatari@gmail.com
}

\begin{abstract}
The main objective of the study is to review the research conducted about online banking, focusing on the effect of the Covid-19 pandemic on using online banking services as a marketing channel. The study used is the systematic literature review of previous studies, so that these studies included the period before and after the Covid-19 pandemic. From reviewing the online banking research, the study find that the Covid-19 pandemic had a positive impact on the online banking services market, as the pandemic resulted in social distancing laws that led to the resort to electronic services to conduct business, including banking. In addition, this study concluded that among the most important factors affecting the quality of online banking services; availability of security, privacy, ease of use, and trust was the most important from the customer's point of view. The recommendations, we need more research about online banking services, focusing on the limitations and the factors affecting them in the developing countries.
\end{abstract}

Keywords: Online banking, marketing channels, pandemic, social distancing

DOI: $10.7176 /$ RJFA/12-18-01

Publication date:September $30^{\text {th }} 2021$

\section{Introduction}

Online services have crossed the luxury barrier to become one of the necessities of daily life, this change in the perception of online services has occurred gradually for a period. However, with the outbreak of the Covid-19 pandemic, technology has moved from luxury to necessity once. It is today the engine of our daily lives, and everyone is forced to deal with online services and learn how to use them if in time have the option to ignore them. At the same time, pressure is increasing on individuals and institutions, Individuals have to learn how to use online services, where institutions have to adopt online services in providing their services. Moreover, it has become imperative for countries to provide appropriate infrastructure to use online services and provide the requirements, especially in developing countries (Benmoussa \& Almaoui, 2020) (Shihadeh \& Liu, 2019).

For companies and institutions, if online services are used to reduce costs, today it has become a necessity to achieve a competitive advantage in line with the needs and desires of customers (Dauda \& Lee, 2015), especially in the service sector. Banks are one of these institutions that have adopted online services in providing their services. The advantages of using online services; reducing costs, and on the other hand, the needs and desires of customers, it was shown to banks how online services increase customer retention and market share (Li, Lu, Hou, Cui, \& Darbandi, 2021).

In this study, online banking services are defined as those services that banks provide via the internet (Bani Ismail \& Alawamleh, 2017), (Salihu, Metin, Hajrizi, \& Ahmeti, 2019). We propose that the Coronavirus pandemic with the accompanying health and social laws have led to the development and expansion of the online banking services market (Baicu, Gardan, Gardan, \& Epuran, 2020). This development requires companies to keep pace with it for two reasons, the first is to achieve competitive advantage and growth in financial performance (Seiam \& Abu Alnadi, 2014), the second is because this development is imposed because of the new laws, and banks must be ready for it, as universities did in their readiness for distance education. Therefore, the current study reviews the online banking services literature, and linked with the Covid-19 pandemic, therefore focusing on how the pandemic created an urgent need for online banking services, thus expanding its market and increasing its marketing opportunities.

\section{Methodology}

This study analyzes the online banking services literature and linked with the Covid-19 pandemic, thus, finding how individuals and institutions deal with the current issue to cover their needs and achieve their targets. The selected criteria for this review based on papers were published from 2014 to 2021.

\section{Systematic Literature Review}

Online services have become a need in our daily lives, especially after the outbreak of the Covid-19 pandemic, which imposed on society the laws of social distancing. This matter has imposed on all institutions of all kinds to work remotely, as are banks, banks that used to provide online banking services have become obligated to provide these services, to conduct business under the laws of social distancing. 
Many studies have dealt with the subject of online banking services, as they have studied these services and their impact on consumers, as well as the nature of consumers' demand for these services, studying the distribution channels of electronic banking services, and how they are affected by consumer trends, and the factors affecting the quality of these services, and determining Quality elements of the online banking services. Many studies have found that electronic banking services are required by consumers and that it is an important marketing advantage for all banking institutions. Also, post Covid-19 pandemic studies have found that these services have been significantly affected by the pandemic positively, which made the pandemic a marketing opportunity for online banking services.

\subsection{Online Banking Services and the Pandemic}

The study of (Moşteanu, Faccia, Cavaliere, \& Bhatia, 2020) analyzed changes in demand and supply of online banking services because of the socio-financial disruption caused by the Covid-19 pandemic situation. In addition, the financial digitization and digital changes in the banking sector at a global level, and the benefits of digitization for individuals and businesses at the same level, using data from international databases, the study found that the current rules of social restrictions helped companies and individuals learn and apply new communication technologies. If financial institutions, particularly the banking system, were afraid at the start of the pandemic, many services are now remote online, rather than communicating face-to-face, financial institutions are now redesigning the structure of their operations including digitization, responding to the demands of new customers.

When measuring the impact of the Covid-19 pandemic on consumer behavior in the online banking services market in Romania, a study of (Baicu , Gardan, Gardan, \& Epuran, 2020) Using the descriptive approach through a questionnaire distributed to the targeted consumers, the questionnaire measured a set of variables affecting consumer behavior in the retail banking services market in the field of internet and telephone. The study showed that there was an increase in the consumption of online banking services during the Corona pandemic period than in the previous period in Romania. What the research recommended is that banks spread the awareness and education about online banking services to increase the ability of customers to use them, especially the elderly who are not immersed in technology.

The results are corresponding to what we mentioned previously about the need for banks to carry out awareness marketing campaigns for online banking services, and the way they are used, and that one of their quality factors is to be easy to use.

In India, the results were not different, were study by (Jindal \& Sharma, 2020) using the descriptive approach through a questionnaire targeting consumers in the city of Bulandshahr in India, looked at evaluating the role of online banking services in fighting the Covid-19 pandemic, the results of study showed that online banking has an important role in fighting the Corona pandemic and that people who use online banking services feel more secure under the conditions of the spread of the virus. Thus, technology has not only gone beyond the daily need, but has become a need for life and a sense of security, and online banking services are required by every banking institution to preserve people's lives.

This is confirmed by a study by (Kushnir \& Hevorhyan , 2020) on Ukrainian banks using the descriptive approach, which found that banks forced to work in uncertain conditions and to organize ways and procedures for working with customers under difficult conditions during the imposed quarantine period, and banks must provide remote services to customers, which in turn is an appropriate solution and safe for both the bank and its customers.

The study recommended a set of recommendations that can say to be appropriate to confront any situation similar to the Covid-19 pandemic. By providing convenient online services in mobile applications, increasing the number of possible transactions in these applications, canceling the commission for using point-of-sale devices and mobile applications, and extending the validity of the card, and pay other services with the card.

Implementing such procedures and establishing an electronic financial market that does all these actions will bring great benefits to customers and greater benefits to banks that will get rid of a lot of paperwork in the branches.

The need to transition to a digital banking model has been talked about for a long time, but the Covid-19 pandemic has made the need to cut operational costs and improve digital experiences more important than ever (Kelecic, 2020). With an electronic financial system and online banking services that keep pace with the requirements of individuals and institutions, companies can provide their services better than before the Covid19 pandemic, and continue to work remotely to transform into it as fully as possible.

\subsection{Online Banking Services}

(Benmoussa \& Almaoui, 2020) examined the limitations that banks face in providing online banking services, using a literature review methodology, and how to overcome them to provide online banking services according to typical requirements. One of its results is that there is a lack of legislation and laws that regulate online 
banking in developing countries. Were (Salem, Baidoun, \& Walsh, 2019) found that there is a lack of studies dealing with the status of online banking services in developing countries such as the Arab world in general, this study, which dealt with online banking services in Palestine, also recommended that the state work on formulating laws and regulations necessary for the work of online banking services.

However, other challenges could be added, such as people's knowledge of technology. Banking services are received from everyone and there is a segment of customers who do not master the use of online services. Therefore, the provision of online banking services requires cooperation between banks as a service provider, the state as a legislator of the laws to provide this service, and the customer who learns the technology will help build an electronic financial system that is beneficial for both parties, the banks, and the customers.

(Li, Lu, Hou, Cui, \& Darbandi, 2021) using a descriptive and questionnaire model, found that the use of online banking channels is associated with higher customer retention rates; it also found evidence that the market share of the sample company in the research is also systematically higher in markets with high usage rates of online banking channels. This confirms the aspect of online banking services in that it is a basic competitive advantage in the institutions, and its transformation, in light of the Covid-19 pandemic period into a need for the institution, not just a competitive advantage.

From the financial point of view, the study of (Seiam \& Abu Alnadi, 2014) using a questionnaire distributed over a sample study that consists of financial managers at Jordanian commercial banks. found how the impact of online banking services was on the financial performance of commercial banks in Jordan, and how it is affected by the efficiency of online banking services, provide that with time, effort, and daily business volumes are saved, and thus reduce expenses and employee costs. Therefore, it recommended that the obstacles that prevent the effective application of online banking services been overcome by paying attention to the quality of online banking services that are provided.

(Shihadeh F. , 2020) analyzed the relationship between consumer behavior and the use of online banking services in daily life, by collecting information from World Bank's 2014 Global Findex Database, and found that the use of online banking services is linked to several factors: the educational level of individuals, age, gender, income level. And that the use of online banking services is still low in the countries of the MENAP region, and that individuals who have a high level of education are more likely to use online banking services. The study recommended that lawmakers work side by side with banking service providers such as banks to provide online banking services that are less expensive and easier to use. The study also recommended studying the relationship between the Covid-19 pandemic and the use of online banking services.

\subsection{Online Banking Services and Quality}

A study by (Rawwasha, et al., 2020) aimed to identify the factors affecting the use of online banking services in Jordan, through a field survey of the study population using a questionnaire. The study found four factors affecting online banking services in Jordan, which are expected benefits, privacy, ease of use, and trust. Based on the results of this study, trust is the strongest contribution to online banking services adoption compared to other variables. The Bank provides adequate security protection to prevent unauthorized intrusion so that the users of online banking services feel comfortable when using the online banking services for their business. Online banking can help Jordanian banks gain a competitive advantage by lowering labor costs and improving customer service; Enhance flexibility, improve access to information, and eliminate most manual or paperwork.

The recommendation that Jordanian banks need to carry out more intensive marketing campaigns, which aimed to increase customers' awareness regarding to the online banking services. Further, banks could focus their efforts on security issues and provide safer online services to customers, and Jordanian banks need to reevaluate user interfaces of the online banking services to ensure ease of use by customers.

Previously (Bani Ismail \& Alawamleh, 2017) through a questionnaire and interviews clarified the impact of online banking services on customer satisfaction in Jordanian banks and identified the strengths and weaknesses of online banking systems in Jordanian banks. The results of this study indicated that account access or control, ease of use, privacy, and security are important determinants of customer satisfaction with online banking services. In Saudi Arabia, a study by (Abualsauod \& Othman, 2019) identified the gaps in the quality of providing online banking services, which are the technology used, dependence on the service, electronic knowledge, and security.

This is consistent with the previous studies of (Bani Ismail \& Alawamleh, 2017) and (Abualsauod \& Othman, 2019), since online banking, services are provided through programs. The main issues in the quality of this program are ease of use, security, and the ability to manage operations through this program, which will naturally reduce the problems associated with providing the service (Salihu, Metin, Hajrizi, \& Ahmeti, 2019), and of course, trust in the institution provides these services. In the study of (Salem, Baidoun, \& Walsh, 2019), the factors affecting the Palestinian customers' use of online banking services were identified. The study consistent with the other studies. That's, the technology used, trust, customer affiliation, security, and privacy were the factors affecting them. 
From previous studies, we can note that adoption the online banking services needs laws to achieve safety and confidence in use. Therefore, the demand of customers for these services, but at the same time, the main role of the customer remains to learn the necessary technology, which is what banks must do through their marketing Awareness programs, (Shihadeh, Gamage, \& Hannon, 2019).

\subsection{Online Banking Services and Distribution Channels}

(Dauda \& Lee, 2015) analyzed the adoption of the technology approach for customers and its impact on the development of online banking services in Nigerian banks by a random utility model using discrete choice models. What this study found was that banks, to achieve a competitive advantage, should provide smart and practical online banking services. Especially services of a personal service nature and the addition of other services that make online banking services more enjoyable, effective, and fast, such as electronic wallets, and that smartphones and websites can increase the approach of adopting technology in the online banking services sector by consumers.

Therefore, we return to the results of a study of (Benmoussa \& Almaoui, 2020) that governments in developing countries should provide the necessary capabilities to implement online banking services because customers are ready to use these services. In the study of ( $\mathrm{Li}, \mathrm{Lu}, \mathrm{Hou}, \mathrm{Cui}, \&$ Darbandi, 2021) the factors that affect customer satisfaction with online banking services are identified using the descriptive-analytical method and the questionnaire. The factors are the use of cloud services, security, e-learning, and the quality of services provided. The paper recommended focusing on people who do not use the internet, motivating and encouraging them to use online banking, and this will be easy with the presence of a good internet infrastructure that facilitates the process of establishing an effective electronic financial market, especially in the developing countries.

\section{Conclusions and Recommendations}

Banking services are the main driver of the market (Shihadeh, Hannon, Guan, ul Haq, \& Wang, 2018) and online banking services are the convenient method to carry out financial operations, whether to protect against a pandemic such as a Covid-19 or to accelerate business and reduce costs.

From the previous studies, that were reviewed, we found that the Covid-19 pandemic provided the online banking services market with an opportunity, that everyone was forced to use online banking services. This opportunity for which institutions were doing many marketing works, to motivate customers to move to use online banking services, which made the customers accept these services, even when there is a defect in their quality.

Banks could take advantage of the opportunity that everyone is compelled to use online banking services, and make their marketing efforts to facilitate this need, to create a competitive advantage in obtaining or retaining customers. In addition, to pay attention to the basic issues in the quality of banking services, which are security, ease of use, and privacy, which is strengthened by the bank's image, and customers trust in it, as well as the existence of laws that protect all parties in these electronic transactions.

Moreover, we recommend more research to find the relationship between the pandemic and using online banking services. More research could be conducted in developing countries, and also in poor areas.

\section{References}

Abualsauod, E. H., \& Othman, A. M. (2019). A study of the effects of online banking quality gaps on customers' perception in Saudi Arabia. Journal of King Saud University - Engineering Sciences.

Baicu, C. G., Gardan, I. P., Gardan, D. A., \& Epuran, G. (2020). The impact of COVID-19 on consumer behavior in retail banking. Evidence from Romania. Management \& Marketing. Challenges for the Knowledge Society, 15, 534-556. doi:10.2478

Bani Ismail, L., \& Alawamleh, M. (2017). The Impact of Online Banking of Customer Satisfaction in Jordan. Journal of Organisational Studies and Innovation, 4, 1-13.

Benmoussa , O., \& Almaoui, A. (2020). E-banking services between the challenges and requirements of success. Journal of Business Administration and Economic Studies, 2, 445-452.

Campbell, D., \& Frei, F. (2010). Cost Structure, Customer Profitability, and Retention Implications of SelfService Distribution Channels: Evidence from Customer Behavior in an Online Banking Channel. Management Science, 4-24. doi:10.1287

Dauda, S. Y., \& Lee, J. (2015). Technologyadoption:Aconjointanalysisofconsumers' preferenceonfutureonlinebankingservices. InformationSystems.

Jindal, M., \& Sharma, V. L. (2020). Usability of Online Banking in India during Covid-19 Pandemic. International Journal of Engineering and Management Research, 10, 69-72.

Kelecic, P. (2020). Covid-19 crisis: Opportunity for banks to reshape service models and foster digital transformation. INTERNATIONAL JOURNAL OF CONTEMPORARY BUSINESS AND 
ENTREPRENEURSHIP, 1, 50-61.

Kushnir, S. O., \& Hevorhyan , H. A. (2020). APPLICATION OF ANTI-CRISIS MEASURES BY THE BANKS OF UKRAINE ABOUT THE PROVISION OF BANKING SERVICES IN THE CONTEXT OF A PANDEMIC OF CORONAVIRUS. Bulletin of Zaporizhzhia National University. Economic sciences, 3, 106-110. doi:https://doi.org/10.26661/2414-0287-2020-3-47-19

Li, F., Lu, H., Hou, M., Cui, K., \& Darbandi, M. (2021). Customer satisfaction with bank services: The role of cloud services, security, e-learning and service quality. Technology in Society. doi:https://doi.org/10.1016/j.techsoc.2020.101487

Moşteanu, N. R., Faccia, A., Cavaliere, L. P., \& Bhatia, S. (2020). DIGITAL TECHNOLOGIES' IMPLEMENTATION WITHIN FINANCIAL AND BANKING SYSTEM DURING SOCIO DISTANCING RESTRICTIONS - BACK TO THE FUTURE. International Journal of Advanced Research in Engineering and Technology, 11(6), 307-315. doi:10.34218/IJARET.11.6.2020.027

Rawwasha, H., Masa'd, F., Enaizan, O., Eneizan, B., Adaileh, M. J., Saleh, A. M., \& Almestarihi, R. (2020). Factors affecting Jordanian electronic banking services. Management Science Letters, 10, 915-922. doi:10.5267/j.msl.2019.10.004

Salem, M. Z., Baidoun, S., \& Walsh, G. (2019). Factors affecting Palestinian customers' use of online banking services. International Journal of Bank Marketing. doi:https://doi.org/10.1108/IJBM-08-2018-0210

Salihu, A., Metin, H., Hajrizi, E., \& Ahmeti, M. (2019). The Effect of Security and Ease of Use on reducing the problems/deficiencies of Electronic Banking Services. (pp. 159-163). International Federation of Automatic Control. doi:10.1016/j.ifacol.2019.12.465

Seiam, A. Z., \& Abu Alnadi, M. A. (2014). The Impact of the Efficiency of Electronic Banking Services to the Financial Performance of the Commercial Banks of Jordan. Al-Quds Open University Journal for Research and Administrative and Economic Studies, 1, 319-336.

Shihadeh, F. (2020). Online payment services and individuals' behaviour: new evidence from the MENAP. International Journal Electronic Banking, 2, 275-282. doi:https://doi.org/10.1504/IJEBANK.2020.114763

Shihadeh, F. H., Hannon, A. M., Guan, J., ul Haq, I., \& Wang, X. (2018). Does Financial Inclusion Improve the Banks'Performance? Evidence from Jordan. Global Tensions in Financial Markets, 117-138. doi:https://doi.org/10.1108/S0196-382120170000034005

Shihadeh, F., \& Liu, B. (2019). Does financial inclusion influence the Banks risk and performance? Evidence from global prospects. Academy of Accounting and Financial Studies Journal, 1-12. doi:https:/www.abacademies.org/articles/Does-Financial-Inclusion-Influ-ence-the-Banks-Risk-and-Performance-1528-2635-23-3-403.pd

Shihadeh, F., Gamage, S., \& Hannon, A. (2019). The Causal Relationship Between SME Sustainability and Banks' Risk. Economic Research-Ekonomska Istraživanja, 2743-2760. doi:https://doi.org/10.1080/1331677X.2019.1655465 